\title{
Structure, Conduct and Performance of Sesame Farmers in Benue State, Nigeria
}

\author{
Nwalem, Monday Patrick ${ }^{1}$, Ukpe, UdemeHenrietta ${ }^{2}$, Djomo, Raoul Fani*1, \\ Dzever Donald ${ }^{1}$ \\ ${ }^{1}$ Department of Agricultural Economics, University of Agriculture, Makurdi, \\ PMB 2373 Makurdi, Benue State, Nigeria \\ ${ }^{2}$ Department of Agricultural Economics and Extension, Federal University Wukari, \\ PMB 1020 Wukari, Taraba State, Nigeria \\ *raoulfani@gmail.com
}

\begin{abstract}
It has been argued that farmers are the least benefit in the marketing chain as far as marketing encompasses all of the business activities performed in directing the flow of goods and services from the producer to the consumer or final user. This study was therefore carried out to analyse structure, conduct and performance of sesame farmers in Benue State, Nigeria using descriptive statistics. A combination of purposive and random sampling techniques was used for sample selection. Data were obtained through the use of a structured questionnaire, copies of which were administered to the selected 372 sesame farmers andwere analyzed using descriptive statistics such as: marketing margin, marketing efficiency, Gini coefficient.It was found that sesame business is profitable with a marketing margin (M.M) of 68433764.25 Naira. The study further revealed that sesame farmers are economically efficient with a marketing efficiency (M.E) of 4.20 and finally sesame business is competitive as well as there is inequality of income among sesame farmers with a Gini coefficient of 0.54. It was recommended that: Government should invest on rural development projects in order to reduce production and marketing cost and sesame farmers should form a cooperative union in order to facilitate group sales which will increase their marketing margin.
\end{abstract}

Keywords: Gini coefficient, Marketing margin, Market efficiency, Sesame Farmers

\section{INTRODUCTION}

Sesame (Sesamumindicum) belongs to the plant family Pedaliaceacommonly called beniseed in Nigeria. It is an important oilseed crop believed to have originated from tropical Africa, where there is the greatest genetic diversity. It was later taken at a very early date to India where a secondary centre of diversity was developed (Purseglove, 1996; Nwalem, 2015). Oplingeret al. (2007) and Nwalem (2015) indicated it to be a highly prized oilseed crop in Babylon and Assyria about 4,000 years ago. In Nigeria, sesame is cultivated on over 80,000 ha across most of the Northern States for food and oil. Benue and Nasarawa States are the highest sesame producers in Nigeria with an annual average output of not less than 40,000MT (Raw Materials Research and Development Council (RMRDC), 2004; Nwalem, 2015). Sesame seeds (approximately 50 percent oil and 25 percent protein) are used in baking, candy making, in cooking and salad oil and margarine. The oil can also be used in manufacture of soaps, paints, perfumes, insecticides and pharmaceuticals. Sesame meal, left after the oil is pressed from the seed, is an excellent high protein (34-50 percent) feed for poultry and livestock (Oplingeret al. 2007; Nwalem, 2015). As a raw export commodity, sesame seed from Nigeria is enjoying a rising profile in the world market where overall global demand has risen to 3.3 million tons. Sesame, like other raw agricultural communities, has over $15 \%$ margin in terms of value added products compared to other crops (RMRDC, 2004; Nwalem, 2015).In marketing system, the structure, conduct and performance of a market is one of the most important approaches to analysis of market. This encourages the participation of a large number of individuals at various types of markets and exchange points where the marketing services of assembling, storage, processing, transportation and break-of-bulk are performed (Egbeadumah, 2008). Market structure includes the level of concentration of buyers and sellers; the level of product differentiation; the conditions of entry to the market. Market conduct refers to possible practices of collusion or exclusion, in addition to pricefixing methods. Finally, performance is evaluated by means of price analyses - price correlation between markets; seasonal price variations; deconstruction of prices; costs and margins between 
players. The closer the structure, conduct and performance are to a situation of pure and perfect competition (no barriers to entry, price taker agents and no excess profits), the better the market is seen to perform (Egbeadumah, 2008). An important variable in market structure analysis is concentration, which shows a situation in which a few large firms have the largest share of business. The effects of market structure, conduct and performance can go a long way in affecting the supply response of agricultural products, especially in cereals processing and marketing(Egbeadumah, 2008). Therefore, there is need to analyze structure, conduct and performance of sesame farmers in Benue State, Nigeria.

\section{Methodology}

\subsection{The Study Area}

Benue State derives its name from River Benue, the second largest River in Nigeria. The State, created in 1976, is located in the middle Belt region of Nigeria, approximately between latitudes $612^{0}$ and $812^{0}$ North and longitude $71 / 2^{0}$ and $10^{0}$ East. The State shares boundaries with five states namely, Nasarawa to the North, Taraba to the East, Cross River to the South-East, Enugu to the South- West, and Kogi to the West. The Southern part of the State also shares boundary with the Republic of Cameroon. The State is also bordered on the North by $280 \mathrm{~km}$ River Benue, and is traversed by 202 $\mathrm{km}$ of River Katsina-Ala in the inland areas. Benue State has a tropical climate, which manifests two distinct seasons. The rainy season is from April to October while the dry season is from November to March. Annual average rainfall varies from $1750 \mathrm{~mm}$ in the Southern part of the State to $1250 \mathrm{~mm}$ in the North.

\subsection{Population, Sampling Procedure and Data Collection}

A combination of purposive and random sampling techniques were used for sample selection. Benue State is divided into three (3) agricultural zones such as: Zone A, Zone B and Zone C.Two local government areas each were purposely selected from Zone A and Zone B while three local government areas were purposely selected from zone $\mathrm{C}$ on the basis of high level of sesame production. Based on this, Kwande and Logo Local Government Areas were purposively selected from Zone A. Guma and Tarka Local Government Areas were purposively selected from Zone B. Oju, Obi and Ohimini Local Government Areas were purposively selected from Zone C. From each of the selected Local Government Areas, households were randomly selected on the basis of its population size using $0.2 \%$ sampling fraction. Based on the foregoing, 372 sesame producers were randomly selected for this study. The primary data were obtained through the use of a structured questionnaire, copies of which were administered to the selected 372 sesame farmers in Benue State.

\subsection{Variable Specification/Model Specification}

Marketing Margin (MM): It was used as measure of market conduct. Following Fadipeet al. (2015) marketing margin (MM) can be computed as:

$\mathrm{MM}=\mathrm{TR}-\mathrm{TC}$

Where,

Total Revenue $=$ TR

Total Cost $=\mathrm{TC}$ (production and marketing cost)

Marketing efficiency (M.E): It was used as a measure of market performance to evaluate sesame price among producers.

Market Efficiency (M.E) $=\frac{\text { Total Revenue }}{\text { Total Cost }}$

Market structure: Gini coefficient was used to assess the structure of sesame producers in the study area. This analytical procedure was used to determine the degree of market concentration among major sesame producers in the study area.

Following Fadipeet al. (2015) Gini coefficient (G) was computed as follows: 
$G=1-\sum_{i}^{k} X_{i} Y_{i}$

Where

$X_{i}=$ Proportion of producers

$Y_{i}=$ Cumulative proportion of annual sales

$K=$ Number of classes

The Gini coefficient ranges from 0 to 1 , where 0 implies perfect equality in the distribution (perfect market) and 1 implies perfect inequality (imperfect market). The closer the Gini coefficient is 0 , the greater the degree of equality and the lower the level of concentration and the more competitive.

\section{RESULTS AND DisCUSSION}

\subsection{Marketing Margin (Market Conduct)}

The marketing margin (M.M) is the difference between total revenue and total cost (production cost and marketing cost)

Total Revenue $=$ TR

Total Cost $=$ TC (production and marketing cost)

$\mathrm{TR}=89760520$

$\mathrm{TC}=21326755.75$

M.M = TR-TC = 89760520-21326755.75 = 68433764.25 Naira

The result of marketing margin shows that sesame business is profitable

\subsection{Marketing Efficiency (Market Performance)}

A market is efficient when marketing efficiency equals to or is greater than one and a market is inefficient if the marketing efficiency is less than one.

The result of Market Efficiency (M.E) is 4.20 and shows that for every naira invested, 4.20 naira is realized. Therefore, sesame farmers in Benue State are economically efficient.

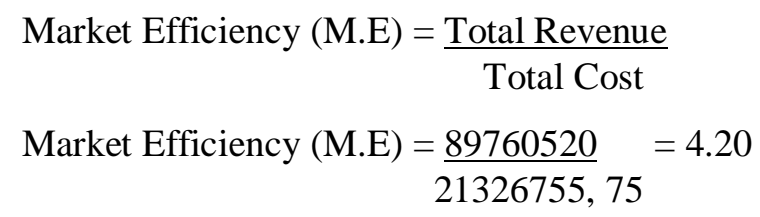

\subsection{Market Structure}

Table 1 summarized the annual sales made by sesame farmers and was categorized with an interval of $\$ 199000$. Table 1 shows that $59.9 \%$ of sesame producers who fall into annual sales of 1-200000 naira control $31.8 \%$ of the market share, $28.7 \%$ of sesame producers who are in the category of 200001-400000 naira annual sales control 33.3\% of the market share, 3.4\% of the sesame producers who are in the category of 400001-600000 naira annual sales control $4.1 \%$ of the market share, $3.4 \%$ of the sesame producers who are in the category of 600001-800000 naira annual sales control $10.8 \%$ of the market share, $2.6 \%$ of sesame producers who are in the category of 800001-1000000 naira annual sales control $7.7 \%$ of the market share, $0.5 \%$ of sesame producers who are in the category of 1000001-200000 naira annual sales control 2.8\% of the market share and $1 \%$ of sesame producers who are in the category of 1200001 and above annual sales control $9.3 \%$ of the market share.

The Gini coefficient is 0.54 and shows that inequality exists in revenue realization by sesame producers. With a Gini coefficient value of 0.54 which is not closer to 1 . This result when compare to the value (0.43) and (0.50) obtained by Fadipeet al. (2015) in their study on analysis of cocoyam marketing in Sagamu Local Government Area, Ogun State, Nigeria indicates that sesame market is competitive in Benue State, Nigeria. 
Nwalem, Monday Patrick et al.

Table1. Average annual sales of sesame producers in Benue State, Nigeria

\begin{tabular}{|l|l|l|l|l|l|l|}
\hline $\begin{array}{l}\text { Category } \\
\text { of sales } \\
(\mathbf{\#})\end{array}$ & $\begin{array}{l}\text { Number } \\
\text { of sesame } \\
\text { producers }\end{array}$ & $\begin{array}{l}\text { Proportion of } \\
\text { producers } \\
\left(\boldsymbol{X}_{\boldsymbol{i}}\right)\end{array}$ & $\begin{array}{l}\text { Total value } \\
\text { of } \begin{array}{c}\text { Proportion } \\
\text { sales (\#) }\end{array}\end{array}$ & $\begin{array}{l}\text { Cumulative } \\
\text { of annual } \\
\text { sales }\left(\boldsymbol{Y}_{\boldsymbol{i}}\right)\end{array}$ & $\begin{array}{l}\text { (\#) } \\
\text { proportion of } \\
\text { annual sales }\end{array}$ & $\mathbf{X}_{\mathbf{i}} \mathbf{Y}_{\mathbf{i}}$ \\
\hline $1-200000$ & 223 & 0.599 & 26790755 & 0.318 & 0.318 & 0.190 \\
\hline $200001-400000$ & 107 & 0.287 & 28068865 & 0.333 & 0.651 & 0.186 \\
\hline $400001-600000$ & 13 & 0.034 & 3477500 & 0.041 & 0.692 & 0.023 \\
\hline $600001-800000$ & 13 & 0.034 & 9165000 & 0.108 & 0.8 & 0.027 \\
\hline $\begin{array}{l}800001- \\
1000000\end{array}$ & 10 & 0.026 & 6500000 & 0.077 & 0.877 & 0.022 \\
\hline $\begin{array}{l}1000001- \\
1200000\end{array}$ & 2 & 0.005 & 2394000 & 0.028 & 0.905 & 0.04 \\
\hline$\geq 1200001$ & 4 & 0.01 & 7840000 & 0.093 & 1 & 0.01 \\
\hline Total & $\mathbf{3 7 2}$ & & $\mathbf{8 4 2 3 6 1 2 0}$ & & & $\mathbf{0 . 4 6}$ \\
\hline $\begin{array}{l}\text { Gini } \\
\text { Coefficient }\end{array}$ & $\mathbf{0 . 5 4}$ & & & & & \\
\hline
\end{tabular}

Sources: Field Survey, 2015

$G=1-\sum_{i}^{k} X_{i} Y_{i}$

$G=1-0.46=0.54$

\section{CONCLUSION AND RECOMMENDATIONS}

This study was carried out to analyse structure, conduct and performance of sesame producers in Benue State, Nigeria. It was found that sesame business is a profitable with a marketing margin (M.M) of 68433764.25 Naira. The study further revealed that sesame farmers are economically efficient with a marketing efficient (M.E) of 4.20 and finally sesame business is competitive as well as there is inequality of income among sesame farmers with a Gini coefficient of 0.54 . It was recommended that:

- Government should invest on rural development projects in order to reduce production and marketing cost

- Sesame farmers should form a cooperative union in order to facilitate group sales which will increase their marketing margin

- Government should also regulate price in order to protect sesame farmers.

\section{REFERENCES}

Egbeadumah, M. O. (2008). Structure Conduct and performance of Tomato Marketing in Abeokuta South, Ogun state. B.Sc. project submitted to the Department of Agricultural Economics. University of Agriculture, Abeokuta,OgunState, Nigeria.

Fadipe, A.E.A., Adenuga, A.H., and Raji, U.A. (2015). Analysis of cocoyam marketing in Sagamu Local Government Area, Ogun State, Nigeria

Nwalem, M.P. (2015).Relationship between level of adverse effect of perceived dimensions of climate change manifestations and production efficiency among sesame farmers in Benue State, Nigeria.M.Sc. Thesis submitted to the Department of Agricultural Economics. University of Agriculture, Makurdi-Benue State, Nigeria.

Oplinger, E.S., Putnam, D.H., Kaminski, A.R., Hanson, C.V., Oelke. E.A., Schulte,E.E.and Doll, J.D. (2007). Alternative Field Crops Mannual: Sesame. Retrieved fromhttp://www.hort.purdue.edu/ newcrop/afcm/sesame.html.

Purseglove, J.W. (1996). Tropical Crops. Longman, London, 435pp. 


\section{AUTHORS' BIOGRAPHY}

Nwalem, Monday Patrick, is a $\mathrm{PhD}$ at the department of agricultural economics, Federal university of agriculture, Makurdi-Benue State.

Ukpe, Udeme Henrietta, is a $\mathrm{PhD}$ at the department of agricultural economics, Federal university of agriculture, Makurdi-Benue State and lecturer at the federal university wukari, Taraba-State, Nigeria

Djomo, Raoul Fani, is a $\mathrm{PhD}$ at the department of agricultural economics, Federal university of agriculture, Makurdi-Benue State.

Dzever Donald, is a M.Sc.student at the department of agricultural economics, Federal university of agriculture, Makurdi-Benue State. 